\title{
PODER SANCIONATÓRIO DOS CONSELHOS DE FISCALIZAÇÃO PROFISSIONAL: REFLEXÃO SOBRE HIPÓTESE DE INELEGIBILIDADE DA LEI DA FICHA LIMPA
}

\section{SANCTIONATIVE POWER OF PROFESSIONAL COUNCILS: REMARK ON INELIGIBILITY HYPOTHESIS STATED IN THE CLEAN RECORD LAW}

\author{
${ }^{1}$ Heron de Jesus Garcez Pinheiro \\ ${ }^{2}$ Roberto Carvalho Veloso
}

\section{RESUMO}

Este artigo expõe controvérsias afetas à inelegibilidade oriunda de decisão administrativa de autarquia profissional, a partir de levantamentos doutrinário e jurisprudencial. Discorre-se sobre a importância histórica dos Conselhos de Fiscalização, gizando-se os pressupostos para a natureza jurídica das referidas entidades, a partir de opção do legislador pelo modelo de autorregulamentação dos países da Europa Continental, o qual as distingue de outros agrupamentos privados. Delineia-se o fundamento do poder sancionatório, destinado a coibir irregularidades em atividades profissionais potencialmente lesivas, analisando-se, por derradeiro,as implicações da cassação de inscrição profissional em pedidos de registro de candidaturaà Justiça Eleitoral.

PALAVRAS-CHAVE: Direitos Políticos; Lei da Ficha Limpa; Inelegibilidade; Infração Ética; Conselho Profissional

\begin{abstract}
This article exposes controversies about ineligibility due to administrative decision by Professional Councils, based on legal literature and case law researches. We point at the historical significance of the Regulatory and Monitoring Councils, emphasizing judicial nature of those governmental entities, facing up the legislative option for self-regulation model brought from Continental European countries, which distinguish them from other professional and private corporations. This study focus on the grounding of power to impose penalties aiming to avoid legal infractions potentially harmful. We analyze, at last, the implications of professional licensure repeal in electoral requests sent to Courts.
\end{abstract}

KEYWORDS: Political Rights; Clean Record Law; Ineligibility; Ethical Infraction; Professional Council

\footnotetext{
${ }^{1}$ Advogado e Mestrando do Programa de Pós-Graduação em Direito e Instituições do Sistema de Justiça da Universidade Federal do Maranhão - PPGDIR/UFMA, Maranhão, PI, (Brasil). E-mail: herongarcez@hotmail.com.

${ }^{2}$ Doutor em Direito pela Universidade Federal do Pernambuco - UFPE, Pernambuco, PE, (Brasil). Professor do Programa de Pós-Graduação em Direito e Instituições do Sistema de Justiça da Universidade Federal do Maranhão - PPGDIR/UFMA, Maranhão, PI, (Brasil). E-mail:
} 


\section{INTRODUÇÃO}

Com a edição da Lei da Ficha Limpa ( $\operatorname{LC~}^{\circ}$ 135/2010), que alterou a redação da Lei de Inelegibilidades (LC $\mathrm{n}^{\mathrm{o}}$ 064/1990), o ordenamento jurídico pátrio conferiu inédita relevância aos julgamentos de infrações ético-profissionais pelos órgãos sancionatórios competentes dos Conselhos de Fiscalização Profissional.

Com o novel diploma, a punição de exclusão do exercício profissional aplicada em desfavor de pessoas físicas registradas em autarquias corporativas passou a implicar suspensão de direitos políticos por 8 (oito) anos, quando decorrentes de transgressões graves na prática dos atos de profissão.

Imprecisões terminológicas na Lei da Ficha Limpa passaram a suscitar dúvidas em intérpretes e aplicadores do direito quanto ao sentido e alcance de designações como "órgão profissional competente" e "infrações ético-profissionais", já havendo as referidas controvérsias batido às portas da Justiça Eleitoral.

Apresenta-se entendimento tocante à repercussão eleitoral das decisões administrativas de cassação de registro de profissionais liberais por órgãos sancionatórios de Conselhos de Fiscalização Profissional, à luz da Lei da Ficha Limpa, com destaque para casos concretos julgados pela Justiça Eleitoral.

Em termos pragmáticos formulam-se os seguintes problemas: a decisão de uma federação, confederação ou justiça desportiva teria o condão de provocar inelegibilidade em um atleta profissional que infringisse eticamente o estatuto ao qual vinculado? A mera inadimplência de um profissional com sua entidade corporativa que culminasse com cassação de registro afigurar-se-ia como causa de inelegibilidade?

O objetivo deste trabalho é apresentar uma proposta de resolução dessas controvérsias a partir de incursões mais aprofundadas no histórico e nas funções dos Conselhos de Fiscalização Profissional, na natureza jurídica dessas entidades e nos fundamentos do poder sancionatório destinado a coibir infrações ético-profissionais.

Empregou-se a título de metodologia levantamento bibliográfico da escassa produção doutrinária sobre as autarquias corporativas no Brasil, com abordagem da jurisprudência preponderante sobre o assunto, em especial do Supremo Tribunal Federal. Procedeu-se, ainda, levantamento dos precedentes da Justiça Eleitoral (TSE e TREs) que já enfrentaram questões 
atinentes ao impacto da sanção de exclusão de Conselho Profissional em pleitos de registro de candidatura.

\section{HISTÓRICO E FUNÇÃO DOS CONSELHOS DE FISCALIZAÇÃO PROFISSIONAL}

A organização dos seres humanos em categorias profissionais remonta à Antiguidade Clássica. Na Grécia Antiga foram registradas as primeiras organizações corporativistas da história, as denominadas hetérias, cujo funcionamento era autorizado pela Lei de Sólon (RUSSOMANO, 1997).

Já na Roma Antiga, no período que data dos primeiros tempos da República até o Império, surgiram os chamados collegia, impostos como engrenagens da Administração no fito de dividir a população consoante as artes e ofícios praticados, além de dirimir contendas no âmbito de determinada atividade artesanal (PEREIRA et al., 2009).

No Digesto, as corporações dispunham de autonomia para aprovar seus próprios regulamentos, desde que não contrastassem com as leis do Estado Romano, tendo sido mantida a Lei de Sólon sob a designação de CollegiisetCorporibus.

Os colégios profissionais romanos (Corpora) destacavam-se por terem sido compostos por integrantes de profissões reputadas essenciais e imprescindíveis à vida coletiva, uma vez que constituíam órgãos oficiosos do Estado Romano, reunindo privilégios e a prerrogativas de fazer arrecadações fiscais. Os membros dessas facções faziam votos perpétuos às profissões e exerciam verdadeiro munus publicum.

$\mathrm{Na}$ Idade Média, as poderosas corporações de ofícios arregimentavam trabalhadores urbanos, em geral produtores e artesãos, de acordo com suas atividades profissionais. Estruturadas sob rígida hierarquia, eram integradas pelos mestres, companheiros e aprendizes (FARIA, 2012).

Aos primeiros cabia o comando dos agrupamentos profissionais, com máxima firmeza; aos segundos, profissionais graduados que aspiravam ao posto de mestre, cabia a responsabilidade pela produção; e aos últimos competia a aprendizagem do ofício ensinado. As corporações de ofício também possuíam tribunais que julgavam litígios atinentes às relações de trabalho (MARTINS, 2006). 
Entretanto, sucedeu que as corporações profissionais medievais passaram a configurar, ao longo do tempo, uma estrutura hermética de opressão dos seus integrantes, pois tantos os companheiros como os aprendizes eram submetidos a inexoráveis exações pelos mestres, os quais tinham poderes quase absolutos sobre seus subordinados.

No mesmo período, os companheiros egressos das corporações de ofício, descontentes com o regime de exploração praticado, passaram a jungir-se nas companhias, nas quais preponderava uma maior autonomia e liberdade para o exercício profissional, acarretando a quebra da hegemonia corporativa (PEREIRA et al., 2009).

Com as revoluções liberais do século XVIII, mais acentuadamente na França e na Inglaterra, as mudanças econômicas e nas relações de trabalho, bem como o ideário iluminista de valorização das artes, letras, humanismo e cientificismo impuseram sepultamento das sólidas bases corporativistas medievais. A palavra de ordem passou a ser liberdade para os exercícios profissional e laborativo, passando a ser inadmissível a existência de grupamentos e corporações entre o Estado e indivíduos (SANCTIS, 2009).

De outro turno, o trabalho até então desenvolvido artesanalmente pelas corporações passaram a ser executados em grande escala pelas massas de trabalhadores das indústrias. Os conflitos oriundos das relações trabalhistas eram resolvidos sem intermediários, entre patrões/empregados e profissionais liberais/clientes. Toda essa onda liberal também chegou ao Brasil, cujas primeiras Constituições (1824 e 1981) asseguravam a liberdade para o exercício profissional.

A Constituição do Império de 1824, no Título $8^{\circ}$ que versava sobre Disposições Gerais e Garantias dos Direitos Civis e Políticos dos Cidadãos Brasileiros, estabelecia nos incisos XXIV e XXV do artigo $179^{3}$ que nenhum gênero de trabalho, cultura, indústria ou comércio pode ser proibido, desde que não se oponha aos costumes públicos, segurança e saúde dos cidadãos, também abolindo expressamente as Corporações de Ofícios, com todos os seus juízes, escrivães e mestres.

No mesmo diapasão, a Constituição Republicana de 1891 consignava a competência privativa do Congresso Nacional para legislar sobre o trabalho (art. 34, item 28), erigindo em sua Declaração de Direitos, capitulada no artigo 72, § 24, na Seção II do Título IV, que é

\footnotetext{
${ }^{3}$ Constituição Imperial de 1824: Art. 179. A inviolabilidade dos Direitos Civis, e Politicos dos Cidadãos Brazileiros, que tem por base a liberdade, a segurança individual, e a propriedade, é garantida pela Constituição do Imperio, pela maneira seguinte. (...) XXIV - Nenhum genero de trabalho, de cultura, industria, ou commerciopóde ser prohibido, uma vez que não se opponha aos costumes publicos, á segurança, e saude dos Cidadãos. XXV - Ficam abolidas as Corporações de Officios, seus Juizes, Escrivães, e Mestres.
} 
garantido o "livre exercício de qualquer profissão moral, intelectual e industrial" (FARIA, 2012).

No início do século XX, percebeu-se o exagero da onda liberalizante e que a liberdade para o desempenho de profissões e trabalhos não poderia constituir-se como direito absoluto dos cidadãos, no propósito de salvaguardar a incolumidade social de práticas laborais potencialmente lesivas.

A esse propósito, valha-nos o magistério do Professor Miguel Reale (1983, p. 92), a saber:

Com o desaparecimento dos estatutos corporativos, prevaleceu, em primeiro momento, a mais ampla liberdade de ação, chegando-se a conhecidos exageros, como, por exemplo, o de não subordinar a prática de Medicina à prévia obtenção do diploma universitário, por entender-se tal exigência contrária à liberdade individual. Nem faltaram, para tais entendimentos, motivos ideológicos, como os que, por equívoco, se fundaram na filosofia positivista de Augusto Comte.

Após a Primeira Guerra Mundial, com a replicação da experiência americana das agências reguladoras após a crise de 1929, foram retomadas as ideias sobre intervenção do Estado na economia, de modo a regular-lhe o funcionamento, no desiderato de concretizar determinados objetivos coletivos postos em relevo pela questão social.

A intensa efervescência provocada pelo ideário marxista, que culminou com a Revolução Russa de 1917, contribuiu decisivamente para o restabelecimento da concepção de que o Estado não poderia abster-se completamente da regulação da ordem econômica e das relações de trabalho. Em contraposição e reação à influência comunista soviética, emergiu na Itália com o fascismo a denominada Carta del Lavoro, a qual estabelecia rigoroso controle estatal das relações trabalhistas e do exercício profissional (MOREIRA, 1997).

Em mitigação aos efeitos do liberalismo econômico que não conseguia resolver convulsões sociais no princípio do século XX, as Constituições do México (1917) e de Weimar (1919) inovaram ao introduzir nos catálogos jurídicos questões sociais, trabalhistas e de intervenção estatal na ordem econômica (PINHEIRO, 2006).

Em temperamento à ampla liberdade consagrada em diplomas anteriores, a Constituição de 1934 estatuiu pela primeira vez na história jurídica pátria requisito para o regular desempenho de atividade profissional, subordinando-o à capacidade técnica que a lei

\footnotetext{
${ }^{4}$ Constituição Republicana de 1891: Art.72 - A Constituição assegura a brasileiros e a estrangeiros residentes no paiz a inviolabilidade dos direitos concernentes á liberdade, á segurança individual e á propriedade, nos termos seguintes: (...) § 24. É garantido o livre exercicio de qualquer profissão moral, intellectual e industrial.
} 
estabelecer na consecução do interesse público ${ }^{5}$. Referida regra foi mantida nas Constituições posteriores, com pequenas alterações de redação.

Destarte, a partir de década de 1930, o Estado passou a intervir no exercício das profissões, notadamente nas de caráter técnico-científico, fazendo-o mediante pessoas jurídicas criadas exclusivamente para tal finalidade, seguindo tendência descentralizadora, para não executar diretamente referida incumbência (PEREIRA et al., 2009).

Nessa perspectiva, o Brasil adotou o modelo europeu continental de autorregulamentação profissional, uma vez que as entidades responsáveis pela referida tarefa têm natureza jurídica de direito público. Disciplina distinta foi empregada na Inglaterra, que agasalhou a autorregulamentação privada através de associação voluntária.

As diferenças entre os modelos inglês e europeu continental de autorregulamentação profissional encontram-se elucidativamente traçadas por Vital Moreira (1997, p. 54 e 88):

No primeiro caso, as instâncias de auto-regulação são estabelecidas por autovinculação dos interessados, de forma voluntária, na base do direito privado e da liberdade negocial. No segundo caso, as instâncias de auto-regulação são impostas ou reconhecidas oficialmente pelo Estado e dotadas de poderes de normatização e de disciplina obrigatória idênticos aos do Estado.

(...)

A auto-regulação pública é a que é protagonizada por organismos profissionais ou de representação profissional dotados de estatutos jurídico-públicos. A autoregulação é legalmente estabelecida; os organismos auto-regulatórios dispõem de poderes típicos das autoridades públicas. As normas de regulação profissional são para todos os efeitos normas jurídicas dotadas de coercibilidade. [...] nos sistemas de direito administrativo continental, o exemplo mais típico de auto-regulação profissional é a das ordens profissionais, que são organismos de regulação das chamadas profissões liberais. O seu nome e número varia de país para país. Mas, para além dessas diferenças, subsiste um conjunto de características comuns essenciais: a natureza jurídico-pública, como "corporações públicas" (exceptuado o caso controvertido da França); a filiação obrigatória como condição do exercício da profissão; o poder regulamentar; a regulamentação e/ou implementação de regras de acesso à profissão e ao exercício desta; a formulação e/ou aplicação de códigos de deontologia profissional; o exercício da disciplina profissional, mediante aplicação de sanções, que podem ir até à expulsão, com a consequente interdição do exercício profissional.

O pioneirismo no estudo das agremiações profissionais e da divisão do trabalho coube a Durkheim, considerado o fundador da moderna sociologia. Defendia a regulamentação profissional feita por um corpo de integrantes da mesma profissão, por conhecer bem o seu funcionamento e sentir todas as necessidades e variações desta. Ademais,

\footnotetext{
${ }^{5}$ Constituição de 1934: Art. 113 - A Constituição assegura a brasileiros e a estrangeiros residentes no País a inviolabilidade dos direitos concernentes à liberdade, à subsistência, à segurança individual e à propriedade, nos termos seguintes: (...) 13. É livre o exercício de qualquer profissão, observadas as condições de capacidade técnica e outras que a lei estabelecer, ditadas pelo interesse público.
} 
preconizava que essas corporações deveriam ter caráter institucional público, colimando evitar agregados confusos e sem unidade (DURKHEIM, 2004).

A Constituição Federal de 1988 contempla como direito o livre o exercício de qualquer trabalho, ofício ou profissão, cujo desempenho poderá condicionar-se ao atendimento das qualificações profissionais que a lei infraconstitucional estabelecer ${ }^{6}$. Cuidase de norma constitucional de eficácia contida, pois produz efeitos jurídicos desde logo, independentemente de integração, porém poderá ter eficácia restringida por norma legal superveniente (SILVA, 1998).

Ressalte-se, outrossim, a competência da União Federal exarada no art. 21, inciso XXIV, da Carta da República para o estabelecimento da organização, manutenção e execução da inspeção do trabalho, atividade que engloba a fiscalização das profissões regulamentadas. O texto maior dispõe, ainda, que a União Federal detém a competência privativa para legislar sobre as condições para o exercício profissional (art. 22, CF).

No tocante à função típica de Estado desempenhada pelos Conselhos de Fiscalização Profissional, por delegação da União, no controle e policiamento das profissões regulamentadas, transcreva-se esclarecedor excerto de publicação do Tribunal de Contas da União - TCU (2014, p. 28-29):

A União passou a delegar progressivamente a sua função de fiscalizar o exercício profissional, criando por meio de leis específicas os denominados Conselhos de Fiscalização Profissional: pessoas jurídicas de direito público, detentoras de autonomia administrativa e financeira e sujeitas ao controle do Estado para exercer a fiscalização do exercício profissional.

Note-se que a competência privativa para legislar sobre a organização do sistema nacional de emprego e as condições para o exercício das profissões continua vinculada à União, ao passo que aos denominados Conselhos de Fiscalização Profissional foi delegada a competência para aplicação da legislação nacional relacionada ao exercício da profissão.

Em outros termos, em razão do processo de descentralização administrativa, os Conselhos de Fiscalização Profissional aplicam a legislação nacional relacionada ao exercício da profissão que venha a ser desenvolvida e organizada pela União.

Não poderia ser diferente, uma vez que o referido processo de descentralização administrativa não possui o condão de alterar um dispositivo constitucional.

Os conselhos possuem a finalidade de zelar pela integridade e pela disciplina das diversas profissões, disciplinando e fiscalizando, não só sob o aspecto normativo, mas também punitivo, o exercício das profissões regulamentadas, zelando pela ética no exercício destas.

\footnotetext{
${ }^{6}$ Constituição Federal de 1988: Art. $5^{\circ}$. Todos são iguais perante a lei, sem distinção de qualquer natureza, garantindo-se aos brasileiros e aos estrangeiros residentes no País a inviolabilidade do direito à vida, à liberdade, à igualdade, à segurança e à propriedade, nos termos seguintes: (...) XIII - é livre o exercício de qualquer trabalho, ofício ou profissão, atendidas as qualificações profissionais que a lei estabelecer.
} 
Cabe a estas entidades, além de defender a sociedade, impedir que ocorra o exercício ilegal da profissão, tanto por aquele que possua habilitação, mas não segue a conduta estabelecida, tanto para o leigo que exerce alguma profissão cujo exercício dependa de habilitação.

Assim, aos conselhos Profissionais incumbe, com base em legislação específica que regulamenta o exercício profissional das diferentes áreas, estabelecer os mecanismos e requisitos que possam asseguram o exercício eficaz da profissão, assegurando à sociedade um profissional com o adequado perfil técnico e ético.

Para alcançar os objetivos, os Conselhos exercem o poder de polícia administrativa sobre os membros de determinada categoria profissional, apurando situações contrárias às normas, aplicando, caso necessário, a penalidade cabível.

O poder de fiscalizar emana do poder de polícia e requer para seu pleno exercício a discricionariedade, a coercibilidade e a autoexecutoriedade, podendo implicar restrições de direitos individuais em favor dos interesses maiores da coletividade.

(...)

A manutenção de suas atividades, inclusive com o pagamento das despesas inerentes ao seu funcionamento, é realizada pela cobrança de anuidades, ou seja, da cobrança das contribuições sociais devidas pelos profissionais regularmente inscritos em cada conselho profissional.

A primeira entidade de fiscalização profissional criada no Brasil foi a Ordem dos Advogados do Brasil (OAB), em 18 de novembro de $1930^{7}$, responsável pela disciplina e seleção de advogados. Pouco tempo após, em 11 de dezembro de 1933, foi criado o Conselho Federal de Engenharia e Arquitetura (CONFEA) ${ }^{8}$, com atribuição de disciplinar as profissões de engenheiro, arquiteto e agrimensor. Atualmente, existem no Brasil 30 (trinta) Conselhos Federais de Fiscalização Profissional ${ }^{9}$.

\section{NATUREZA JURÍDICA ESTATAL E DISTINÇÃO DE AGREMIAÇÕES PRIVADAS}

\footnotetext{
${ }^{7}$ Decreto do Chefe do Governo Provisório da República dos Estados Unidos do Brasil no 19.408/1930: Art. 17. Fica criada a Ordem dos Advogados Brasileiros, orgão de disciplina e seleção da classe dos advogados, que se regerá pêlos estatutos que forem votados pelo Instituto da Ordem dos Advogados Brasileiros, com a colaboração dos Institutos dos Estados, e aprovados pelo Governo.

${ }^{8}$ Decreto do Chefe do Governo Provisório da República dos Estados Unidos do Brasil no 23.569/1933: Art. 18. A fiscalização do exercício da engenharia, da arquitetura e da agrimensura será, exercida pelo Conselho Federal de Engenharia e Arquitetura e pelos Conselhos Regionais a que se referem os arts. 25 a 27.

${ }^{9}$ Ordem dos Advogados do Brasil, Conselho de Administração, Conselho de Arquitetura e Urbanismo, Conselho de Biblioteconomia, Conselho de Biologia, Conselho de Biomedicina, Conselho de Contabilidade, Conselho de Corretores de Imóveis, Conselho de Despachantes Documentalistas, Conselho de Economia, Conselho de Economistas Domésticos, Conselho de Educação Física, Conselho de Enfermagem, Conselho de Engenharia e Agronomia, Conselho de Estatística, Conselho de Farmácia, Conselho de Fisioterapia e Terapia Ocupacional, Conselho de Fonoaudiologia, Conselho de Medicina, Conselho de Medicina Veterinária, Conselho de Museologia, Conselho de Nutricionistas, Conselho de Odontologia, Conselho de Psicologia, Conselho de Profissionais de Relações Públicas, Conselho de Química, Conselho de Representantes Comerciais, Conselho de Serviço Social, Conselho de Técnicos em Radiologia e Ordem dos Músicos.
} 
A natureza jurídica de direito público dos Conselhos de Fiscalização Profissional tem sido historicamente aclamada, sobretudo diante da opção do legislador pátrio pelo modelo de autorregulamentação dos países da Europa Continental. Nessa senda, têm sido criados por leis específicas, com autonomia administrativa e financeira, no propósito de fiscalizar e controlar o exercício das profissões regulamentadas.

Por elucidativo quanto à perspectiva histórica da natureza jurídica dos Conselhos Profissionais, em cotejo com as finalidades desempenhadas pelas corporações para sedimentação da unidade social ensejadora da formação dos Estados Nacionais, valha-nos escólio de Cotrim Neto (1966 apud STEPKE e DRUMOND, 2011, p. 124):

Autarquias é o que elas efetivamente são, como já o teriam sido as corporações que ajudaram a recompor o Estado, na Idade Média, quando o mesmo buscava encontrar-se, num período difícil de atomização das instituições sociais. E são até autarquias espontâneas, que, além de exercerem uma função pública, correspondem a um agregado social cimentado pela comunhão espiritual dos homens do mesmo ofício.

Nesse diapasão, valha-nos o escólio do administrativista Carvalho Filho (2005, p. 418) sobre o conceito de autarquia:

À luz desses elementos, pode-se conceituar autarquia como a pessoa jurídica de direito público, integrante da Administração Indireta, criada por lei para desempenhar funções que, despidas de caráter econômico, sejam próprias e típicas do Estado.

Ao proceder à classificação das autarquias quanto ao objeto, "dentro das atividades típicas do Estado, a que estão preordenadas", o citado doutrinador mencionou a existência das autarquias profissionais, a par das autarquias assistenciais, previdenciárias, culturais, administrativas e de controle, registrando serem "incumbidas da inscrição de certos profissionais e de fiscalizar sua atividade" (CARVALHO FILHO, 2005, p. 423).

As atividades levadas a cabo pelas entidades de fiscalização profissional afiguram-se consectárias do poder de polícia delegado pelo Estado a referidos sujeitos descentralizados, por motivos de índole eminentemente pragmática. Não há divergência entre intérpretes do ordenamento jurídico pátrio acerca da natureza jurídica autárquica dos Conselhos de Fiscalização Profissional, seja pela expressa referência nas respectivas leis criadoras, seja em 
razão da exata subsunção destes à dicção do art. $5^{\circ}$, inciso I, do vetusto Decreto-Lei $n^{\circ} 200$, de 25 de fevereiro de $1967^{10}$.

Por sua vez, o Decreto-Lei n ${ }^{\circ}$ 968, de 13 de outubro de 1969, tratou de imprimir peculiaridades na natureza jurídica dos Conselhos de Fiscalização Profissional, por serem mantidos com recursos próprios e não receberem subvenções ou transferências à conta do orçamento da União. Dispõe que tais entidades regular-se-ão pela respectiva legislação específica, não se lhes aplicando as normas legais sobre pessoal e demais disposições de caráter geral relativas à administração interna das autarquias federais.

As principais questões a serem apontadas do diploma acima citado, que distinguem as autarquias corporativas das demais, imprimindo-lhes caráter híbrido, são: independência em relação ao orçamento geral da União, por serem mantidas com recursos próprios (anuidades, taxas e multas administrativas); disciplina e administração interna de acordo com as respectivas leis instituidoras, que preveem as formas de escolha dos dirigentes etc.; e inaplicação das normas legais estatutárias sobre pessoal, agasalhando, assim, o regime da Consolidação das Leis do Trabalho - CLT.

Por tais razões, a doutrina administrativista mais abalizada classifica as Ordens e os Conselhos de Fiscalização Profissional como entes com situação peculiar, sendo organismos destinados à regulamentação do exercício das profissões regulamentadas pela legislação federal. Assinala, ainda, que essas entidades são chamadas na doutrina de autarquias paraadministrativas, corporações autárquicas, corporações profissionais e instituições corporativas, tendo sua natureza autárquica regularmente reconhecida pelos Tribunais, mesmo quando as leis instituidoras omitem referida designação (MEDAUAR, 2007).

Tocante aos meandros da natureza jurídica híbrida dos Conselhos Profissionais, merece transcrição a lição de Furtado (2007, p.194):

(...) são criados por lei, desempenham atividade típica de Estado, correspondente ao poder de fiscalizar o exercício das atividades profissionais, gozam de prerrogativas típicas de entidades de Direito Público (tais como imunidade tributária relativas a seus bens, rendas e serviços e possibilidade de cobrança de seus créditos por meio de execução fiscal), sem que, todavia, estejam vinculadas ou subordinada direta ou indiretamente a qualquer entidade política.

\footnotetext{
10 Art. $5^{\mathbf{o}}$ Para os fins desta lei, considera-se: I - Autarquia - o serviço autônomo, criado por lei, com personalidade jurídica, patrimônio e receita próprios, para executar atividades típicas da Administração Pública, que requeiram, para seu melhor funcionamento, gestão administrativa e financeira descentralizada.
} 
Sucede, todavia, que as entidades de fiscalização profissional possuem enorme dinâmica de funcionamento. E apesar de tratarem-se de instituições estatais antigas, pelas incertezas e desatualizações que povoam a legislação, ainda estão em processo de construção, sobretudo pela jurisprudência dos Tribunais Pátrios (FARIA, 2012).

O Supremo Tribunal Federal - STF já decidiu pela submissão dos Conselhos Profissionais a regime jurídico de direito público ao proclamar a inconstitucionalidade material do art. 56 , caput, e $\S \S 1^{\circ}, 2^{\circ}, 4^{\circ}, 5^{\circ}, 6^{\circ}, 7^{\circ}$ e $8^{\circ}$ da Lei $n^{\circ} 9.649$, de 27 de maio de 1998 , face ao inequívoco desempenho de atividades típicas de Estado, a garantir-lhes capacidade tributária ativa, imunidade tributária e múnus público decorrente do exercício do poder de polícia delegado pelo Estado, no que concerne ao exercício de fiscalização das atividades profissionais regulamentadas ${ }^{11}$.

Na mesma esteira, o Superior Tribunal de Justiça - STJ consolidou jurisprudência pelo caráter tipicamente público das autarquias corporativas, destacando a sujeição ao regime jurídico de direito público diante do exercício de atribuições estatais de fiscalização das profissões, em cumprimento aos arts. 5\%, XIII, 21, XXIV, e 22, XVI, da Constituição Federal $^{12}$.

Logo, resta pacificamente assentado pelas maiores Cortes de Justiça brasileiras que os Conselhos Fiscalizadores exercem atividades estatais típicas, ostentando natureza autárquica, ainda que diferenciada, visto que detêm capacidade tributária ativa, imunidade tributária e múnus público decorrente do exercício do poder de polícia delegado pelo Estado, atributos suficientes para fazer-lhes incidir as normas gerais e princípios de direito público.

Ademais, em decorrência da gestão de dinheiro público oriundo de tributos cobrados de contribuintes, mormente contribuições parafiscais, contribuições corporativas e taxas, os Conselhos de Fiscalização sujeitam-se ao controle externo do Tribunal de Contas da União TCU, conforme o seguinte precedente do Excelso Pretório ${ }^{13}$, a saber:

EMENTA: CONSTITUCIONAL. ADMINISTRATIVO. ENTIDADES FISCALIZADORAS DO EXERCÍCIO PROFISSIONAL. CONSELHO FEDERAL DE ODONTOLOGIA: NATUREZA AUTÁRQUICA. Lei 4.234, de 1964, art. $2^{\circ}$. FISCALIZAÇÃO POR PARTE DO TRIBUNAL DE CONTAS DA UNIÃO. I. -

\footnotetext{
${ }^{11}$ STF - ADI no 1717, Relator(a): Min. SYDNEY SANCHES, Tribunal Pleno, julgado em 07/11/2002, DJ 2803-2003, PP-00061, EMENT VOL-02104-01, PP-00149.

12 STJ - REsp 507.536/DF, Rel. Ministro JORGE MUSSI, QUINTA TURMA, julgado em 18/11/2010, DJe 06/12/2010.

${ }^{13}$ STF - MS 21797, Relator(a): Min. CARLOS VELLOSO, Tribunal Pleno, julgado em 09/03/2000, DJ 18-052001 PP-00434 EMENT VOL-02031-04 PP-00711 RTJ VOL-00177-02 PP-00751.
} 
Natureza autárquica do Conselho Federal e dos Conselhos Regionais de Odontologia. Obrigatoriedade de prestar contas ao Tribunal de Contas da União. Lei 4.234/64, art. $2^{\circ}$. C.F., art. 70, parágrafo único, art. 71, II. II. - Não conhecimento da ação de mandado de segurança no que toca à recomendação do Tribunal de Contas da União para aplicação da Lei 8.112/90, vencido o Relator e os Ministros Francisco Rezek e Maurício Corrêa. III. - Os servidores do Conselho Federal de Odontologia deverão se submeter ao regime único da Lei 8.112, de 1990: votos vencidos do Relator e dos Ministros Francisco Rezek e Maurício Corrêa. IV. - As contribuições cobradas pelas autarquias responsáveis pela fiscalização do exercício profissional são contribuições parafiscais, contribuições corporativas, com caráter tributário. C.F., art. 149. RE 138.284-CE, Velloso, Plenário, RTJ 143/313. V. - Diárias: impossibilidade de os seus valores superarem os valores fixados pelo Chefe do Poder Executivo, que exerce a direção superior da administração federal (C.F., art. 84, II). VI. - Mandado de Segurança conhecido, em parte, e indeferido na parte conhecida.

Ilustrativo quanto ao desempenho de função típica de Estado pelas autarquias profissionais, razão pela qual se conclui que estão a serviço da coletividade, devendo ser guiadas exclusivamente para o seu benefício, transcreve-se o seguinte aresto do Superior Tribunal de Justiça - STJ ${ }^{14}$, peremptório quanto à legitimidade ativa dos Conselhos de Fiscalização até para ajuizamento de Ações Civis Públicas - ACPs na defesa de direitos difusos e coletivos, a saber:

AÇÃO CIVIL PÚBLICA. LEGITIMIDADE ATIVA. CONSELHO REGIONAL DE FISCALIZAÇÃO PROFISSIONAL. AUTARQUIA. ART. $5^{\circ}$ DA LEI No 7.347/85. I

- A questão controvertida cinge-se a reconhecer, ou não, a legitimidade ativa do Conselho Regional de Técnicos de Radiologia da $5^{\text {a }}$ Região, substituído em sede recursal pelo Ministério Público Federal, para o ajuizamento de Ação Civil Pública visando à regularização da atividade de Radiologia no "Hospital e Pronto Socorro Infantil Gonzaga". II - A Lei ${ }^{\circ}$ 7.394/85, que criou o Conselho Federal e os Conselhos Regionais dos Técnicos de Radiologia, e o Decreto $n^{\circ}$ 92.790/86, que a regulamentou, incluíram entre as suas atribuições institucionais a fiscalização do exercício da profissão de técnico em radiologia. III - Essas atividades, consoante concluiu o Colendo Supremo Tribunal Federal, no julgamento da ADIn ${ }^{\circ}$ 1.7176/DF, são típicas do Estado, donde se conclui que estão a serviço da coletividade, devendo ser guiadas para o seu benefício. Essa é a razão pela qual se conceituou a natureza jurídica dessas entidades como de autarquia de regime especial. IV - A preocupação com relação ao exercício de atividade irregular, externada pela Autarquia profissional quando do ajuizamento da Ação Civil Pública, alude a direito social indisponível, notadamente quando se verifica que se dirige à preservação da saúde daqueles que se submetem a exames no hospital ora recorrido. V - Ora, sendo direito coletivo, referente a um agrupamento de pessoas não identificadas, e centrando-se no fundamento constitucional do direito à saúde, não há, data maximavenia, como não se reconhecer a legitimidade ativa da Autarquia profissional criada exatamente para exercer fiscalização que garanta a adequada prestação do serviço essencial à manutenção e preservação da saúde pública. VI - Recurso Especial provido. Afastada a ilegitimidade ativa ad causam da Autarquia Profissional.

${ }^{14}$ STJ - REsp 879.840/SP, Rel. Ministro FRANCISCO FALCÃO, PRIMEIRA TURMA, julgado em 03/06/2008, DJe 26/06/2008). 
Consigne-se, a propósito, a evidente distinção entre os Conselhos de Fiscalização e as entidades privadas de classe, a exemplo de sindicatos e associações de profissionais, uma vez que aqueles submetidos a regime de direito público com a atribuição precípua de controlar e fiscalizar os atos de profissão, julgando processos de infração à legislação profissional e infrações éticas, com poderes para aplicação de penalidades disciplinares e multas. É dizer, cumpre às autarquias fiscalizadoras proteger a sociedade dos maus profissionais e de leigos que pretendam executar ilegalmente profissões regulamentadas.

A tendência verificada na construção jurisprudencial acerca da natureza jurídica dos Conselhos de Fiscalização Profissional aponta para uma aproximação gradual das autarquias ditas típicas, com a superação das peculiaridades preconizadas no Decreto-Lei nº 968/1969, inclusive nos campos da vinculação da gestão interna ao Poder Executivo, integração ao orçamento geral da União e adoção do Regime Jurídico Único (RJU) de pessoal.

\section{INFRAÇÕES ÉTICO-PROFISSIONAIS E PODER SANCIONATÓRIO DOS CONSELHOS DE FISCALIZAÇÃO PROFISSIONAL}

Uma das tarefas conferidas às autarquias corporativas é de proteger a coletividade do potencial lesivo de determinadas atividades profissionais, de modo a coibir condutas praticadas em desconformidade com os protocolos técnico-científicos ou mesmo na hipótese de execução por pessoas físicas e jurídicas inabilitadas para o desempenho dos atos de profissão.

Para tanto, as entidades profissionais estão municiadas de poderes administrativos, que são instrumentos de trabalho da Administração Pública para realização das atribuições que lhes são conferidas pela legislação. Classificam-se em poder vinculado, poder discricionário, poder hierárquico, poder disciplinar, poder regulamentar e poder de polícia, apresentando-se diversificados para satisfazer as plurais exigências do serviço público, o interesse da coletividade e os objetivos a que se dirigem (MEIRELLES, 2005).

As principais tarefas finalísticas outorgadas aos Conselhos de Fiscalização Profissional demandam pormenorização de dois dos poderes administrativos destacados, quais sejam, o poder regulamentar e o poder de polícia administrativa.

Entende-se por poder regulamentar a faculdade de explicar, esclarecer complementar a legislação ordinária para sua fiel e correta execução. Sucede que tradicionalmente referido 
poder é reservado pelo ordenamento aos Chefes dos Poderes Executivos, através de decretos objetivando a instituição de regulamentos de execução ou regulamentos autônomos. Todavia, com os Conselhos de Fiscalização Profissional há exceção digna de nota.

Primeiramente, não se deve vislumbrar como heterodoxia a instituição de mecanismos de complementação das leis pela Administração Pública, mormente quando indispensável à sua efetiva aplicabilidade. Por essa razão, o Direito Administrativo Pátrio erigiu como poder regulamentar a prerrogativa de edição de atos infralegais para subsidiar a execução da legislação ordinária (CARVALHO FILHO, 2005).

No caso dos Conselhos de Fiscalização Profissional, avulta consignar que seria irrazoável exigir do legislador ordinário complexos conhecimentos técnicos para estabelecer detalhamentos e meandros ínsitos às profissões regulamentadas, mormente tendo em perspectiva a autorregulação inerente ao policiamento das profissões.

Hodiernamente, em situações de notória complexidade técnica, tem-se dado vazão no ordenamento jurídico à transferência da competência da lei (domaine de laloi) para outras fontes normativas (domaine de l'ordonnance), em fenômeno conhecido como deslegalização, por expresso beneplácito do legislador. É dizer, a normatização sai do domínio da lei para domínio de ato regulamentar, prestigiando especialistas e técnicos que melhor podem dispor sobre aludidos assuntos (MADEIRA, 2001).

E a transferência ou delegação à Administração para exercício do poder regulamentar não é completa, sujeitando-se aos limites estabelecidos no regramento básico, com espeque em critérios políticos e administrativos, mediante parâmetros expressamente previstos em lei (delegationwithstandards). Nesse sentido a lição de Carvalho Filho (2005, p.54):

\footnotetext{
Modernamente, contudo, em virtude da crescente complexidade das atividades técnicas da Administração, passou a aceitar-se nos sistemas normativos, originariamente na França, o fenômeno da deslegalização, pelo qual a competência para regular certas matérias se transfere da lei (ou ato análogo) para outras fontes normativas por autorização do próprio legislador: a normatização sai do domínio da lei (domaine de laloi) para o domínio de ato regulamentar (domaine de l'ordonnace). O fundamento não é difícil de conceber: incapaz de criar a regulamentação sobre matéria de alta complexidade técnica, o próprio Legislativo delega ao órgão ou à pessoa administrativa a função específica de instituí-la, valendo-se dos especialistas e técnicos que melhor podem dispor sobre tais assuntos.
}

Em termos pragmáticos, o ordenamento pátrio alberga explícita ou tacitamente que as autarquias corporativas editem atos normativos regulamentares para explicar, esclarecer e 
complementar a legislação de regência das profissões ${ }^{15}$. Dentro do poder regulamentar encontra-se o amparo legal para a elaboração dos Códigos de Ética Profissional, expressão maior da autorregulamentação e de cumprimento obrigatório por todos os registrados sob circunscrição de determinada entidade corporativa.

Por poder de polícia entende-se o poder administrativo exercido para condicionar e restringir o uso e gozo de bens, atividades e direitos individuais, em benefício da coletividade ou do próprio Estado. Cuida-se da frenagem da qual dispõe a Administração para arrostar abusos de direitos individuais. A conceituação doutrinária clássica foi absorvida pela abrangente e esclarecedora redação do art. 78 do Código Tributário Nacional - CTN $^{16}$.

Nessa esteira, pode-se conceber que o poder punitivo dos Conselhos de Fiscalização Profissional, consubstanciados em multas, advertências, suspensões ou cassações de registro, exercido em desfavor de profissionais registrados e de leigos que invadem o campo privativo de determinada profissão regulamentada, constitui expressão nítida do poder de polícia administrativa outorgado pelas respectivas leis instituidoras.

\section{LEI DA FICHA LIMPA E DESDOBRAMENTOS ELEITORAIS DA CASSAÇÃO DE REGISTRO PROFISSIONAL}

Os direitos políticos consistem em faculdades por meio das quais os cidadãos exercem a soberania popular, consubstanciando acervo de instrumentos que garantem participação no processo eleitoral, seja mediante o direito de votar (direitos políticos ativos) e/ou através do direito de ser votado (direitos políticos passivos).

Nessa assentada, os direitos políticos negativos originam-se das previsões constitucionais que restringem o acesso do cidadão à representação popular, por meio de impedimentos às candidaturas. Dividem-se em regra sobre inelegibilidade e normas sobre

\footnotetext{
${ }^{15}$ Ver o art. 27, alínea " $\mathrm{f}$ " da Lei Federal $\mathrm{n}^{\circ}$ 5.194/1966, que regulamenta as profissões de engenheiro e agrônomo, ao estabelecer a atribuição do Conselho Federal de Engenharia e Agronomia (CONFEA) para "baixar e fazer publicar as resoluções previstas para regulamentação e execução da presente lei, e, ouvidos os Conselhos Regionais, resolver os casos omissos". Em igual sentido o art. 54, inciso V, da Lei Federal no 8906/1994, que regulamenta a profissão de advogado, ao estabelecer a atribuição do Conselho Federal da OAB para: "editar e alterar o Regulamento Geral, o Código de Ética e Disciplina e os provimentos que julgar necessários".

${ }^{16} \mathrm{CTN}$ : Art. 78 - Considera-se poder de polícia a atividade da Administração Pública que, limitando ou disciplinando direito, interesse ou liberdade, regula a prática de ato ou abstenção de fato, em razão do interesse público concernente à segurança, à higiene, à ordem, aos costumes, à disciplina da produção e do mercado, ao exercício de atividades econômicas dependentes de concessão ou autorização do poder público, á tranquilidade pública ou ao respeito à propriedade e aos direitos individuais ou coletivos.
} 
perda e suspensão dos direitos políticos. A inelegibilidade consiste na ausência de capacidade eleitoral passiva, ou seja, da condição de ser candidato e, consequentemente, de poder ser votado, constituindo-se, portanto, em condição obstativa ao exercício passivo da cidadania (MORAES, 2005).

A redação da Lei Complementar no 135/2010 (Lei da Ficha Limpa) alterou o texto da Lei Complementar $n^{\circ}$ 064/1990 (Lei das Inelegibilidades) para instituir restrições ao direito político de ser votado, em especial para adaptá-lo à disposição do art. 14, § $9^{\circ}$ da Constituição Federal (a partir da ECR n ${ }^{\circ}$ 004/1994), na tutela da probidade administrativa, da moralidade para o exercício da representação popular e da ética na vida política.

Ponto revestido da maior relevância é a previsão de que ficará inelegível, pelo prazo de 08 (oito) anos, aquele que for excluído do exercício da profissão por decisão sancionatória do órgão profissional competente, em decorrência de infração ético-profissional, salvo hipótese de anulação ou suspensão do ato pelo Poder Judiciário (art. $1^{\circ}$, inciso I, alínea "m" da LC no 064/1990).

As imprecisões jurídicas do diploma em comento suscitam dúvidas sobre o genuíno sentido e alcance da aludida disposição normativa ensejadora de inelegibilidade. Afigura-se, inelutável, pois, superar interpretação meramente gramatical para examinar o preceito de maneira sistemático-teleológica, objetivando assegurar a máxima eficácia à Lei da Ficha Limpa, que constitui conquista legislativa notável da sociedade civil organizada contra malfeitos na vida política nacional.

Em levantamento jurisprudencial sobre processos envolvendo a aplicação do art. $1^{\circ}$, inciso I, alínea “m” da LC no 064/1990 pela Justiça Eleitoral chegou-se às seguintes controvérsias, nenhuma das quais ainda enfrentadas pelo Tribunal Superior Eleitoral - TSE: i) quem são os órgãos competentes sancionadores para aplicação da sanção de exclusão do exercício profissional? eii) quais são as infrações ético-profissionais puníveis com exclusão do exercício profissional e, por conseguinte, acarretadoras da inelegibilidade?

A questão quanto aos órgãos sancionadores competentes para aplicação da sanção de exclusão do exercício profissional foi enfrentada pelo Tribunal Regional Eleitoral do Distrito Federal - TRE/DF no Acórdão no 3985, de 17/08/2010, que tratou de registro de candidatura da ex-nadadora Rebeca Gusmão ao cargo de Deputada Distrital, após sofrer banimento “por toda a vida" por decisão da Federação Internacional de Natação - FINA, ao motivo de infração às regras antidoping daquela instituição desportiva. 
Naquele caso, o julgamento acerca do deferimento do registro de candidatura dependia do entendimento de quais sujeitos estariam institucionalmente aptos a aplicar a sanção de exclusão do exercício profissional. O TRE/DF, por maioria, com desempate do Presidente daquela Corte Regional, decidiu que a Federação Internacional de Natação - FINA não constituía órgão profissional competente para fiscalização do exercício profissional.

Preponderou a divergência segundo a qual as sanções aplicadas por ligas desportivas possuem natureza eminentemente privada e restringem-se às suas próprias competições (art. 50 da Lei $n^{\circ}$ 9.615/1990), não sendo oponíveis contra todos. E, inobstante o desempenho de atividades de atleta profissional, a profissão de nadador não é prevista nos cadastros do Ministério do Trabalho de Emprego - MTE, de modo que não há órgão sancionador competente para aplicação da sanção de exclusão do exercício profissional na seara dos desportos aquáticos.

Por ilustrativo da controvérsia, valha-nos o mencionado aresto do Tribunal Regional Eleitoral do Distrito Federal - TRE/DF ${ }^{17}$ :

EMENTA: PEDIDO DE REGISTRO DE CANDIDATURA - IMPUGNAÇÃO NÃO CONHECIDA - ATLETA - EXCLUSÃO DE COMPETIÇÕES INELEGIBILIDADE INEXISTENTE - DEFERIMENTO.

1 - Não se conhece de impugnação encaminhada por quem não demonstra capacidade postulatória, nem comprova os requisitos do artigo 38 da Resolução $n^{\circ}$ 23.221 - TSE, para aproveitamento como exercício do direito de petição.

2 - Mesmo tendo sido a atleta suspensa "por toda a vida" de competições, o fato não impede o registro da candidatura, uma vez que a entidade que a puniu não é órgão profissional competente para fiscalizar o exercício da profissão.

3 - Pedido deferido. Maioria. Impugnação não conhecida. Unânime.

Não fosse a imprecisão redacional na confecção da LC n ${ }^{\circ}$ 135/2010 não emergiriam tantas dúvidas quanto à intenção do legislador. Tecnicamente, os Conselhos de Fiscalização Profissional não são órgãos. Diante da natureza autárquica reconhecida ex vi legis, tratam-se de entidades públicas que são compostas internamente por órgãos (centros de competência), certamente alguns dos quais sancionadores (art. $1^{\circ}, \S 2^{\circ}$, incisos I e II, da Lei $n^{\circ}$ 9.784/1999).

No entanto, o modelo brasileiro de fiscalização profissional é a autorregulamentação oriunda dos países europeus continentais, de modo que é somente com sanção de cassação de registro pelos órgãos competentes dos Conselhos de Fiscalização Profissional que incidirá a inelegibilidade preconizada na Lei da Ficha Limpa, pois ostentam natureza de direito público

${ }^{17}$ TRE/DF - REGISTRO DE CANDIDATO no 177248, Acórdão no 3985 de 17/08/2010, Relator(a) LUCIANO MOREIRA VASCONCELLOS, Publicação: PSESS - Publicado em Sessão, Data 17/08/2010. 
e têm relações com os profissionais e empresas registrados marcadas pela compulsoriedade (inscrição e recolhimento de anuidades e taxas obrigatórios para exercício profissional lícito).

De outro turno, a questão sobre quais seriam as infrações ético-profissionais puníveis com exclusão do exercício profissional remete às sanções de desligamento de pessoas físicas e jurídicas por motivo de inadimplência. Indubitavelmente, quando o legislador consignou que apenas as infrações ético-profissionais punidas com exclusão do exercício profissional acarretariam inelegibilidade, obviamente reservou a restrição ao direito político de ser votado a quem cometeu transgressão grave no âmbito das respectivas profissões.

As punições pelos Conselhos Profissionais obedecem a gradiente, sendo proporcionais à gravidade da falta cometida. Em geral, infrações leves são sancionadas com advertência; infrações médias com suspensão; e infrações mais graves com cassação de registro. No entanto, algumas leis reguladoras de profissões, objetivando salvaguardar as finanças e a sustentabilidade das autarquias corporativas, estipularam a punição de cancelamento de registro em desfavor de inadimplentes recalcitrantes (FARIA, 2012).

Por tal motivo, há acórdãos nos Tribunais Regionais Eleitorais do Pará ${ }^{18}$ e Espírito Santo $^{19}$ afastando o cancelamento de registro por inadimplência do enquadramento como infração ético-profissional passível de inelegibilidade. A toda evidência, é de se acentuar a razoabilidade do entendimento, uma vez que a transgressão para ser apodada de infração ético-profissional há de ser afeta ao desempenho de um ato de profissão, com conotação jurídico-administrativo-deontológica.

Não é o caso de obrigações de índole tributária, a exemplo do pagamento de anuidades, cuja satisfação há de ser perseguida pelas vias ordinárias de cobrança da Fazenda Pública. A toda evidência, um mero devedor de uma entidade de fiscalização profissional não representaria, em tese, nenhuma ameaça aos bens jurídicos tutelados pela Lei Complementar $n^{\circ}$ 064/1990, que se encontram devidamente relacionados no $\S 9^{\circ}$ do art. 14 da Constituição Federal.

\section{CONCLUSÃO}

18 Registro de Candidatura no 44194, Acórdão no 26686 de 02/08/2014, Relator(a) EZILDA PASTANA MUTRAN, Publicação: PSESS - Publicado em Sessão, Volume 15hr22min, Data 02/08/2014; e Registro de Candidatura $\mathrm{n}^{\circ}$ 85932, Acórdão $\mathrm{n}^{\circ} 26616$ de 30/07/2014, Relator(a) RAIMUNDO HOLANDA REIS, Publicação: PSESS - Publicado em Sessão, Volume 15:00, Data 30/07/2014.

${ }^{19}$ RECURSO ELEITORAL n ${ }^{\text {17280, Acórdão n }}{ }^{\circ} 188$ de 01/08/2012, Relator(a) RACHEL DURÃO CORREIA LIMA, Publicação: PSESS - Publicado em Sessão, Data 01/08/2012. 
À guisa de conclusão, destaque-se que os agrupamentos profissionais sempre desempenharam funções de elevada repercussão social na história, desde a Antiguidade Clássica, passando pelas Idades Média e Moderna. De influência e poderes quase absolutos sobre seus integrantes, o corporativismo passou por crise com as revoluções liberais, mas logo retomou papel de controle e fiscalização das profissões regulamentadas.

A partir da Constituição de 1934, foram estabelecidos sistemas de entidades públicas de fiscalização profissional, com o desiderato de zelar pela integridade e pela disciplina das diversas atividades, controlando e fiscalizando os respectivos desempenhos não somente sob o aspecto técnico-normativo, mas também punitivo, em primado pelo zelo da ética no exercício laboral.

Além de defender a sociedade, cumpre a tais entidades impedir a ocorrência do exercício ilegal da profissão, tanto por aquele que possui habilitação e não segue os protocolos técnicos estabelecidos, como para o leigo que exerce atividade cujo exercício depende de escolaridade, habilitação técnica e inscrição prévia na repartição legalmente responsável.

A natureza jurídica de autarquias federais, sujeitas a regime de direito público, constitui alternativa adotada pelo legislador brasileiro, que aclamou o modelo de autorregulamentação dos países da Europa Continental. Contudo, interesses privados sempre atuaram na tentativa (às vezes exitosa) de captura dessas entidades, de modo a conformar regime autárquico híbrido mais condizente com as conveniências dos fiscalizados do que com o interesse público.

Detentoras de poderes sancionatórios consectários dos poderes regulamentar e de polícia, as autarquias corporativas têm o poder-dever de estabelecer e fazer cumprir seus respectivos regulamentos jurídico-administrativo-deontológicos, inclusive mediante punição dos infratores, com observância dos cânones do devido processo legal, com contraditório e ampla defesa.

Nesse cenário, a Lei da Ficha Limpa erigiu a sanção de exclusão do exercício profissional a patamar de causa de inelegibilidade, desde que decorrente de infrações éticoprofissionais, passível de suspensão de direitos políticos pelo prazo de 08 (oito) anos, caso não sejam suspensas ou invalidadas pelo Poder Judiciário. 
Sustenta-se que o disposto no art. $1^{\text {o }}$, inciso I, alínea “m” da LC nº 064/1990 alcança somente sanções de cassação de registro aplicadas por órgão legalmente competente dos Conselhos de Fiscalização Profissional, bem como que a inelegibilidade preconizada na Lei da Ficha Limpa não incide quando a exclusão de entidade corporativa decorrer de punição não relacionada efetivamente a falta ética grave no desempenho dos atos de profissão, com conteúdo de desonestidade malfazejo à probidade administrativa, à moralidade para o exercício da representação popular e à ética na vida política.

Portanto, a decisão de uma federação, confederação ou justiça desportiva não tem a força de provocar inelegibilidade em um atleta profissional que infringisse eticamente o estatuto ao qual vinculado, bem como a mera inadimplência de um profissional com sua entidade corporativa que culminasse com cassação de registro não se afiguraria como causa de inelegibilidade, mas somente as punições decorrentes de infrações genuinamente éticoprofissionais com o condão de comprometer a qualidade da representação popular preconizada no art. $14, \S 9^{\circ}$, da Constituição Federal.

\section{REFERÊNCIAS}

CARVAlHO FILHO, José dos Santos. Manual de Direito Administrativo. 12.ed. Rio de Janeiro: Lumen Júris, 2005.

DURKHEIM, Émile. Da Divisão do Trabalho Social. São Paulo: Martins Fontes, 2004.

FARIA, Claude Pasteur de Andrade. Comentários à Lei 5.194/66. 2.ed. Florianópolis: Editora Insular, 2012.

FURTADO, Lucas Rocha. Curso de Direito Administrativo. Belo Horizonte: Fórum, 2007.

MADEIRA, José Maria Pinheiro. Administração Pública Centralizada e Descentralizada. Editora América Jurídica: Rio de Janeiro, 2001.

MARTINS, Sérgio Pinto. Direito do Trabalho. 22.ed. São Paulo: Atlas, 2006.

MEDAUAR, Odete. Direito Administrativo Moderno. 11.ed. São Paulo: Editora Revista dos Tribunais, 2007.

MEIRELLES, Hely Lopes. Direito administrativo brasileiro. 31.ed. São Paulo: Malheiros Editores, 2005. 
MENDES, Gilmar Ferreira; COELHO, Inocêncio Mártires; BRANCO, Paulo Gustavo Gonet. Curso de direito constitucional. 4.ed. São Paulo: Saraiva, 2009.

MORAES, Alexandre de. Direito Constitucional. 17. ed. São Paulo: Atlas, 2005.

MOREIRA, Vital. Auto-Regulação Profissional e a Administração Pública. Coimbra: Livraria Almedina, 1997.

PEREIRA, Ricardo Teixeira do Valle et al. Conselhos de Fiscalização Profissional Doutrina e Jurisprudência. São Paulo: Editora Revista dos Tribunais, 2001.

PINHEIRO, Maria Cláudia Bucchianeri. A Constituição de Weimar e os direitos fundamentais sociais. Biblioteca Digital do Senado Federal. Revista de informação legislativa, v. 43, n. 169 , p. 101-126, jan./mar. 2006. Disponível em: http://www2.senado.leg.br/bdsf/bitstream/handle/id/92449/Pinheiro\%20Maria.pdf?se. Acesso em: 22 de agosto de 2016.

REALE, Miguel. Autarquias Corporativas: Autonomia Financeira. Revista de Direito Público, nº 67, ano XVI, p. 92-99, jul./dez. 1983.

RUSSOMANO, Mozart Victor. Princípios Gerais de Direito Sindical. 2.ed. Rio de Janeiro: Forense, 1997.

SANCTIS, Fausto Martins de. Responsabilidade Penal das Corporações e Criminalidade Moderna. 2.ed. São Paulo: Saraiva, 2009.

SILVA, José Afonso da.Aplicabilidade das normas constitucionais. 3.ed. São Paulo: Malheiros, 1998.

STEPKE, Fernando Lolas; DRUMOND, José Geraldo de Freitas. Ética em engenharia e tecnologia. Brasília: Confea, 2011.

TRIBUNAL DE CONTAS DA UNIÃO. Orientações para Conselhos de Fiscalização das Atividades Profissionais. Agosto de 2014. Disponível em: http://portal2.tcu.gov.br/portal/pls/portal/docs/2663839.PDF. Acesso em: 22 de agosto de 2016. 